Article

\title{
Estimating Nitrogen and Phosphorus Cycles in a Timber Reef Deployment Area
}

\author{
Jamaluddin Fitrah Alam ${ }^{1, *(\mathbb{C}}$, Tamiji Yamamoto ${ }^{1}\left(\mathbb{0}\right.$, Tetsuya Umino ${ }^{1}$, Shinya Nakahara ${ }^{2}$ and \\ Kiyonori Hiraoka ${ }^{2}$ \\ 1 Graduate School of Biosphere Science, Hiroshima University, Higashi Hiroshima 739-8528, Japan; \\ tamyama@hiroshima-u.ac.jp (T.Y.); umino@hiroshima-u.ac.jp (T.U.) \\ 2 Hiroshima Environment and Health Association, Hiroshima 730-8631, Japan; \\ shinya.nakahara@kanhokyo.or.jp (S.N.); kiyonori.hiraoka@kanhokyo.or.jp (K.H.) \\ * Correspondence: alamjamaluddin@outlook.com; Tel.: +81-8062-666-888
}

Received: 26 July 2020; Accepted: 3 September 2020; Published: 9 September 2020

\begin{abstract}
In an oligotrophic bay, Mitsu Bay, Japan, artificial timber reefs (ATRs) are deployed to increase fish production. In such man-made ecosystems, the biological activities of other organisms as well as the physical structures of ATRs could influence nutrient cycling. A pelagic-benthic coupling model expressing both phosphorus and nitrogen cycling was developed to investigate seasonal variation in the associated nutrients and their annual budget in the ATR areas and the entire bay system. The model consists of equations representing all the relevant physical and biological processes. The model reproduced the observed seasonal variations in dissolved inorganic $\mathrm{P}$, ammonium, and nitrate concentrations that were low in spring and summer and high in autumn and winter. The internal regeneration rates of the nutrients were two times higher in the ATRs than in the bay area, so that fish production was predicted to be higher in the ATRs than in the bay area. Considering the inflows from the land and precipitation are quite low, nutrient regeneration is an important source of nutrients for the water in Mitsu Bay. ATR deployment could be an important local nutrient source in an oligotrophic bay, and could increase fish production.
\end{abstract}

Keywords: artificial reef; phosphorus; nitrogen; nutrient cycling; Mitsu Bay; modeling

\section{Introduction}

The Seto Inland Sea, Japan, has been a eutrophicated coastal area owing to industrialization and urbanization activities in the 1960s. However, currently, the coastal marine environment is oligotrophic because of the strict implementation of nutrient discharge reduction measures in line with the Law Concerning Special Measure for Conservation of the Environment of the Seto Inland Sea, enacted in 1979 [1]. The condition of Mitsu Bay (MB), in the western part of the Seto Inland Sea, is also oligotrophic, and oyster farming in the bay is hampered by poor phytoplankton concentrations. In addition, fish catch in the bay is low [2]. Consequently, the deployment of artificial timber reefs (ATRs) (Figure S1) was initiated by the local Higashi-Hiroshima City government with the support of the central government, in a project named Regional Revitalization and Local Residents Life, such as Emergency Assistance Grant (Local Creation Proactive) 2015, Cabinet Office, Government of Japan. From the second year, Higashi-Hiroshima City has been overseeing successive research projects, from November 2015 to 2018 [3-6].

ATRs facilitate the development of habitats for various marine organisms in the deployment area of MB [7]. The encrusting of algae on the ATR surfaces followed by the invasion of other organisms sustains newly established food webs, which eventually attract fish and enhance fish catch. 
Several factors influence the habitat development processes, including nutrient supply, which regulates primary production.

However, the material cycles through food webs established among fish and feed organisms have not been investigated quantitatively. Organisms attached to ATRs and fish that gather can serve as nutrient sources through their physiological activities such as excretion and egestion. In the former process, ammonium and urea are excreted, and in the latter process, organic matter and feces are produced and are finally decomposed and released into water as nutrients, such as ammonium and phosphate. In addition, natural mortality may be high during spawning by fish and other organisms at ATRs. The deposition of organic matter through such physiological activities and dead matter that settle on the sea floor also facilitate the organic enrichment of benthic environments. In addition to facilitating biological processes, ATR structures act as traps that collect organic particles from neighboring areas by decreasing the speed of currents [8,9]. Furthermore, other physical processes, reflected in water movement, which facilitate the constant exchange between water in the ATR deployment areas and the surrounding area in $\mathrm{MB}$, are key factors that influence the nutrient status in the deployment area.

Several studies on the modeling of nutrient cycling in natural coastal ecosystems have been conducted $[10,11]$. Similar attempts to evaluate the success of environmental management activities have been made in man-made ecosystems such sea aquaculture systems [12,13]. In the present study, we estimated nutrient cycling in a new man-made ecosystem established within the ATR systems and bay area based on a pelagic-benthic coupling model. The model consists of two major elements, nitrogen $(\mathrm{N})$ and phosphorus $(\mathrm{P})$, whose dissolved inorganic forms are called "nutrients" and influence the productivity of aquatic ecosystems. Either element can be a limiting factor for the growth of phytoplankton, and they sometimes alternate as limiting factors seasonally and spatially [14]. Therefore, biogeochemical processes are promoted by either element seasonally or spatially based on a benthic-pelagic ecosystem model. However, a numerical model could offer more comprehensive insights on ATR functions.

\section{Materials and Methods}

The present study was conducted in MB, Hiroshima, Japan (Figure 1). The bay is not geographically enclosed, with an open mouth to the Seto Inland Sea. Tidal flow is the major factor driving material transport in the bay, with $0.5-1.2 \mathrm{~cm} / \mathrm{s}$ in the northern half and up to $2.0 \mathrm{~cm} / \mathrm{s}$ at the bay mouth [15]. The major components are the principal lunar semi-diurnal (M2) and the solar semi-diurnal (S2). The residual flow in the bay is clockwise, and the water enters from the straight between Oshibajima Island and the mainland in the west, going up to the north, and then down to the southeast passing through the mouth. The average water retention time in the bay has been calculated to be 2.5 days [15]. In the model, the water exchange rate was adjusted to reflect all the observed nutrient concentrations, with an average water exchange rate of $0.4 /$ day. 

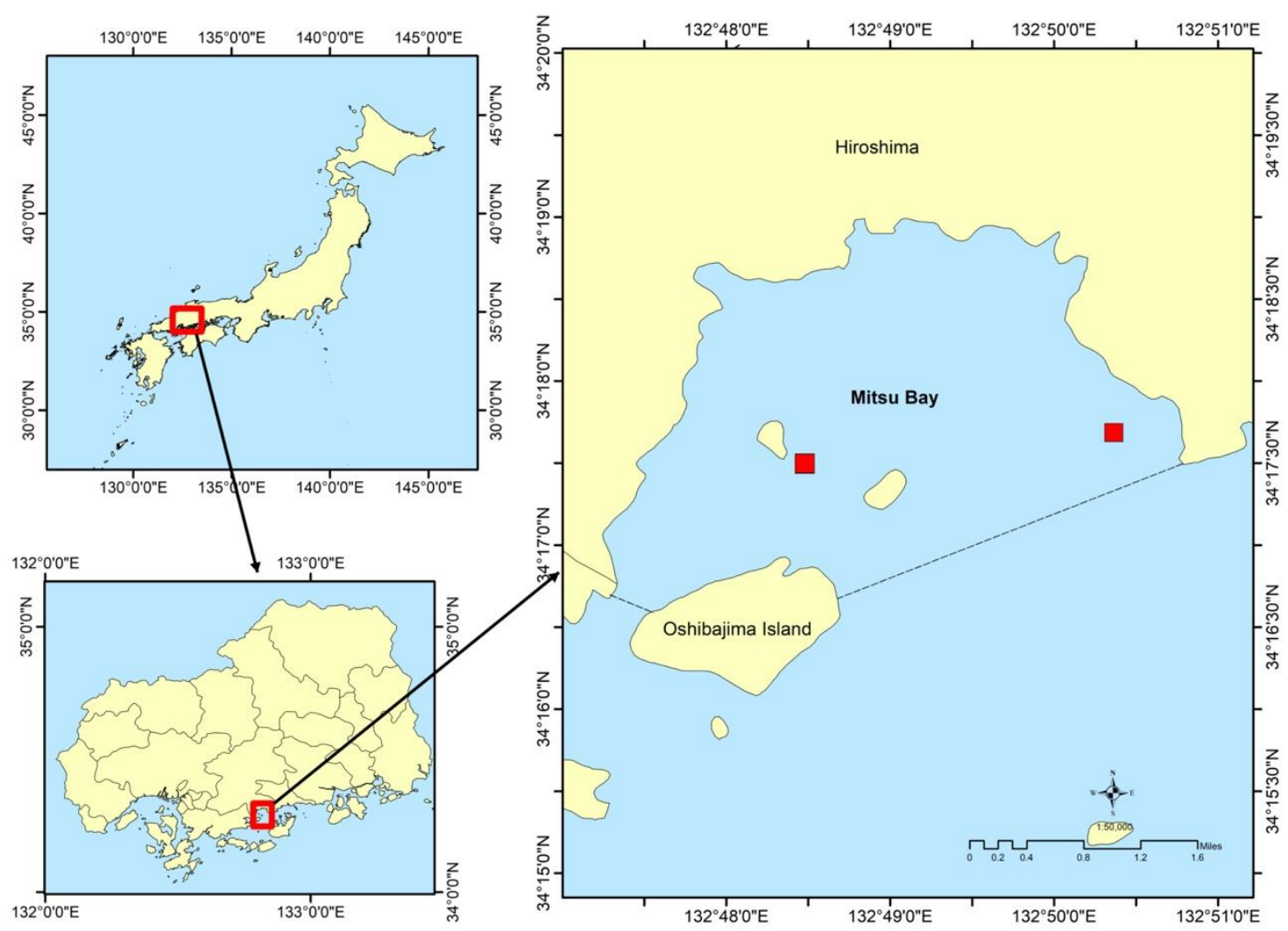

Figure 1. Locations of artificial timber reefs (ATRs) in Mitsu Bay, Higashi-Hiroshima, Japan. Red squares indicate the ATR areas and broken lines indicate the boundaries of the bay.

The present model illustrates the nutrient cycles that occur in the pelagic and benthic systems in the ATRs and surrounding waters in the bay, in addition to the food web models of organisms in the area described in the model of Alam et al. [16]. The volume of the entire MB is $144,000,000 \mathrm{~m}^{3}$, with a surface area of $16,800,000 \mathrm{~m}^{2}$ and an average depth of $8.6 \mathrm{~m}$ [15]. The total area of the two sites where the ATRs have been established was $320 \mathrm{~m}^{2}$, at a depth of $10 \mathrm{~m}$. In the model, we set the total ATR volume to be $3200 \mathrm{~m}^{3}$. The structure of the model was illustrated in Figure 2 and the food web structure was illustrated in detail in Figure S2. Three compartments for different forms of P (detritus P; DET-P, dissolved organic P; DOP, and dissolved inorganic P; DIP), and four compartments for different forms of $\mathrm{N}$ (detritus N; DET-N, dissolved organic N; DON, ammonium; $\mathrm{NH}_{4}^{+}$, and nitrate; $\mathrm{NO}_{3}^{-}$) were applied for both the pelagic and benthic systems. Subsequently, in the MB area, which does not include the ATR area, three P compartments (DET-P_MB, DOP_MB, DIP_MB) and four N compartments (DET-N_MB, DON_MB, $\mathrm{NH}_{4}^{+} \mathrm{MB}$, and $\mathrm{NO}_{3}^{-} \mathrm{MB}$ ) for each pelagic and benthic system were input in the model. DET-N was calculated from DET-P using the Redfield ratio (molar N/P $=16$ ) as a conversion factor [17]. Subsequently, in the MB water, three P compartments (DET-P_MB, DOP_MB, DIP_MB) and four $\mathrm{N}$ compartments (DET-N_MB, $\mathrm{DON} \_\mathrm{MB}, \mathrm{NH}_{4}^{+} \_\mathrm{MB}$, and $\mathrm{NO}_{3-}^{-} \mathrm{MB}$ ) for each pelagic and benthic system were also set to the model to reflect nutrient exchange over time with the materials in the ATR deployment area. Furthermore, there were 21 compartments of living organisms in the ATR area, and eight compartments of living organisms in MB. Their mass balance, parameters, and equations are based on our previously published paper [16]. 


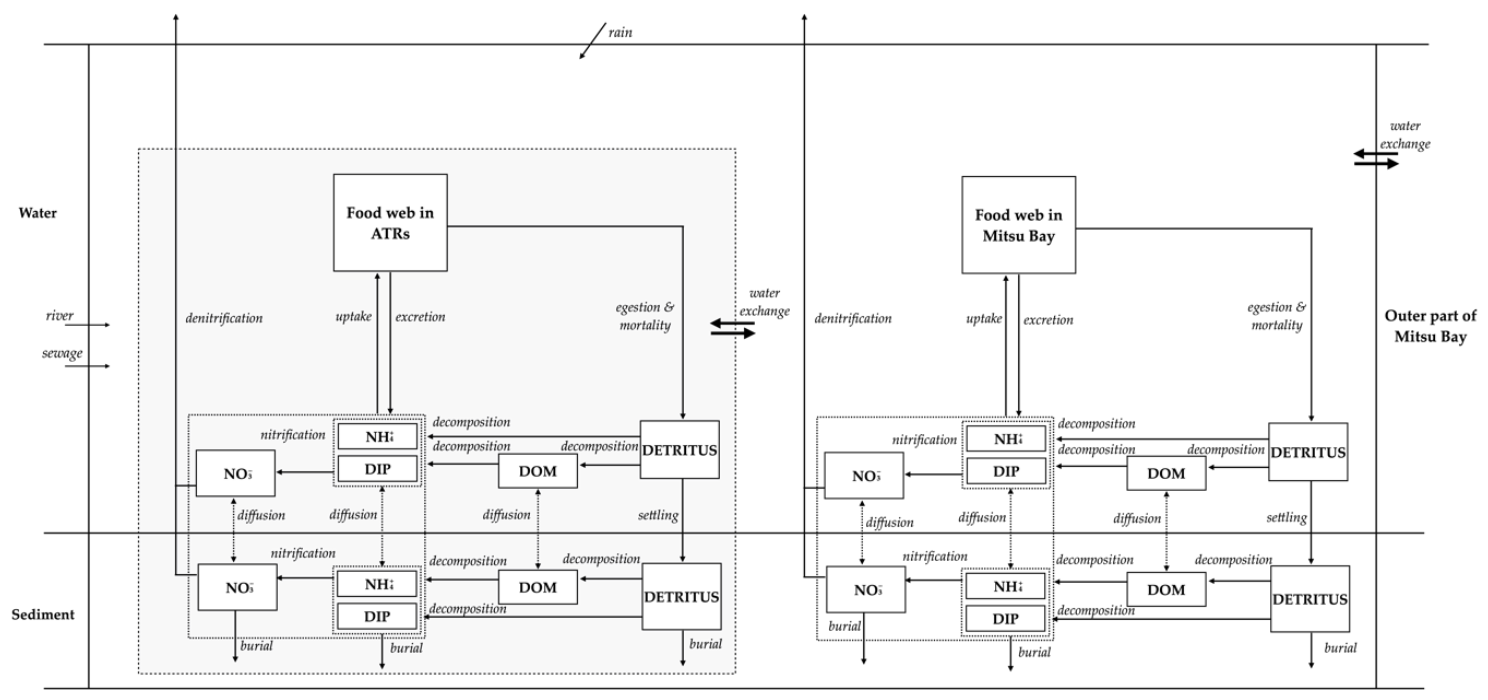

Figure 2. Model framework illustrating nutrient cycling in Mitsu Bay including the artificial timber reef (ATR) areas and other external processes. DOM: dissolved organic matter, DIP: dissolved inorganic phosphorus, $\mathrm{NH}_{4}^{+}$: ammonium, $\mathrm{NO}_{3}^{-}$: nitrate.

$\mathrm{N}$ and $\mathrm{P}$ loads from various sources flowing into $\mathrm{MB}$ were also incorporated into the model. They include material loads from rivers (river DET-N, DON, $\mathrm{NH}_{4}^{+}, \mathrm{NO}_{3}^{-}$, DET-P, DOP, DIP) and sewage treatment plants located in the northern end of the bay (Figure 1) (sewage DET-N, DON, $\mathrm{NH}_{4}^{+}, \mathrm{NO}_{3}^{-}$, DET-P, DOP, DIP [18]. The loading amounts of nutrients from rainfall $\left(\mathrm{prec}_{4} \mathrm{NH}_{4}^{+}, \mathrm{NO}_{3}^{-}, \mathrm{DIP}\right)$ obtained by multiplying the rainwater volume [19] with the reported $\mathrm{DIP}, \mathrm{NH}_{4}^{+}$, and $\mathrm{NO}_{3}^{-}$concentrations in the rainwater [20]. Furthermore, water exchange (inwaterexch, outwaterexch DET-N, DON, $\mathrm{NH}_{4}^{+}$, $\mathrm{NO}_{3}^{-}$, DET-P, DOP, DIP) between the ATR area and the MB area was obtained by multiplying the concentrations in either the ATRs or MB with the water exchange rate estimated from the diffusion and advection processes calculated based on the 3D-flow dynamic model (14). In the $\mathrm{N}$ and $\mathrm{P}$ cycles in the system, excretion (inexc $\mathrm{NH}_{4}^{+}$, DIP) from the animals and fish and decomposed products of detritus matter from the processes of mortality $\left(\mathrm{N}_{\text {totalmortality, }}, \mathrm{P}_{\text {totalmortality }}\right)$ and egestion $\left(\mathrm{N}_{\mathrm{f}}+\mathrm{P}_{\mathrm{f}}\right)$ were considered as recycled nutrient sources that enhance primary production.

The general mass balance equations for the $\mathrm{N}$ and $\mathrm{P}$ cycles are as follows:

In the ATR pelagic system:

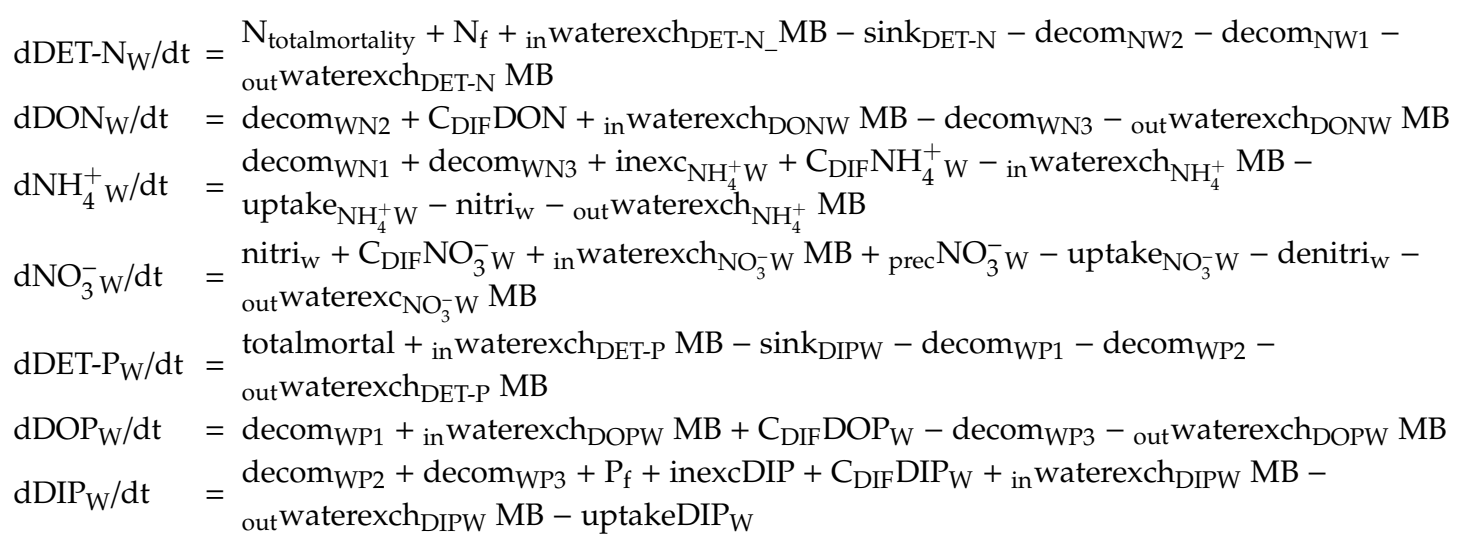

In ATR benthic system:

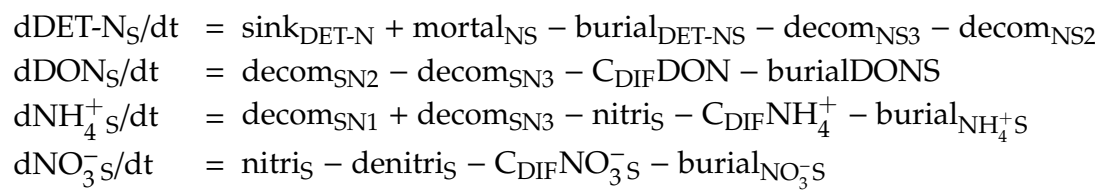




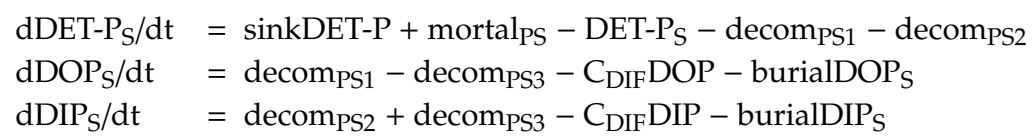

In the Mitsu Bay pelagic system:

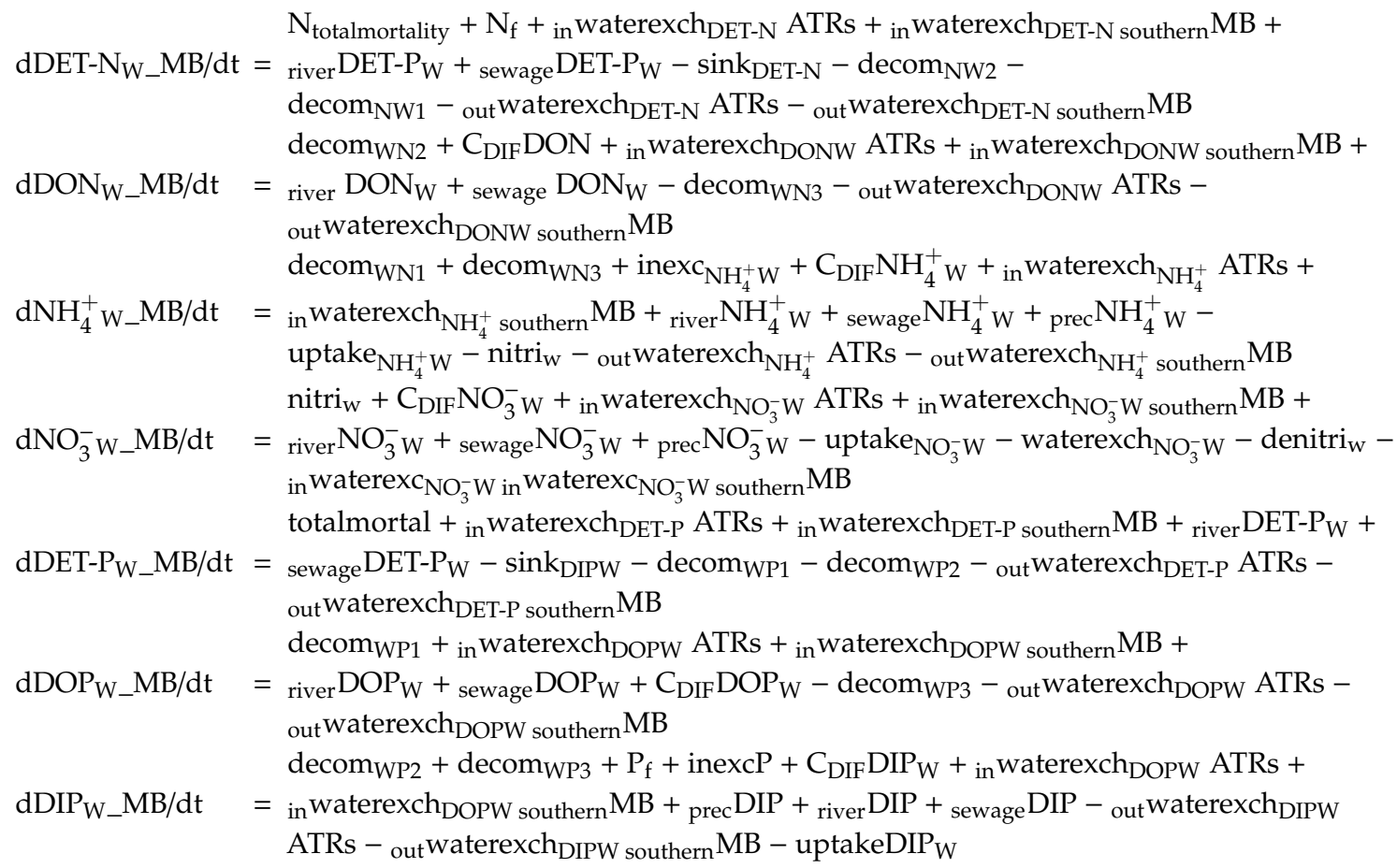

In the Mitsu Bay benthic system:

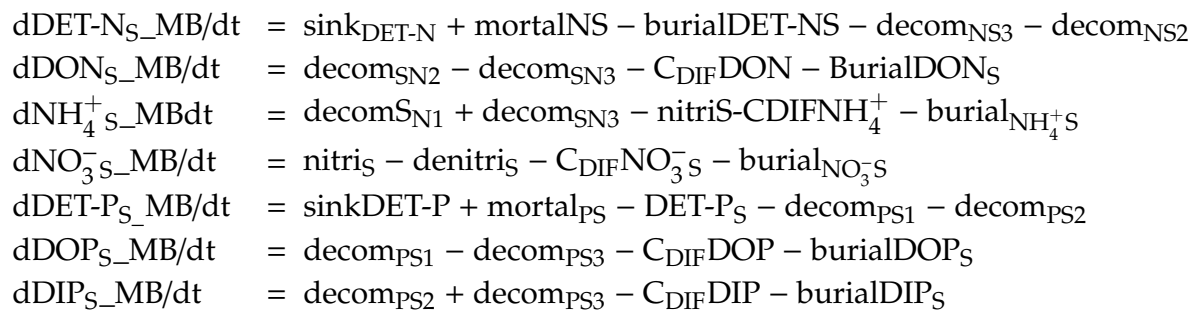

Most of the parameters for the processes in the model are based on literature, and some parameters are tuned (tuning) to obtain an optimal fit to the observed values (Table 1). Environmental parameters such as temperature were obtained using chlorophyll-turbid meters (INFINITY-CLW, JFE Advantech, Co. Ltd., Nishinomiya, Japan), while light intensity and dissolved oxygen (DO) data were obtained from government website [21]. 
Table 1. List of the parameters used in the model.

\begin{tabular}{|c|c|c|c|c|}
\hline Symbols & Definitions & Units & Value & Sources \\
\hline $\mathrm{D}_{\mathrm{DIP}}^{\prime}$ & Diffusion coefficient of DIP & $\mathrm{m}^{2}$ day $^{-1}$ & $5.0 \times 10^{-5}$ & [22] \\
\hline $\mathrm{D}_{\mathrm{DON}}^{\prime}$ & Diffusion coefficient of DON & $\mathrm{m}^{2}$ day $^{-1}$ & $8.0 \times 10^{-5}$ & Tuning * \\
\hline $\mathrm{D}_{\mathrm{DOP}}^{\prime}$ & Diffusion coefficient of DOP & $\mathrm{m}^{2}$ day $^{-1}$ & $7.0 \times 10^{-5}$ & Tuning * \\
\hline $\mathrm{D}_{\mathrm{NH}}^{\prime}$ & Diffusion coefficient of $\mathrm{NH}_{4}^{+}$ & $\mathrm{m}^{2}$ day $^{-1}$ & $8.47 \times 10^{-5}$ & [22] \\
\hline $\mathrm{D}_{\mathrm{NO}}^{\prime}$ & Diffusion coefficient of $\mathrm{NO}_{3}^{-\frac{4}{4}}$ & $\mathrm{~m}^{2}$ day $^{-1}$ & $8.45 \times 10^{-5}$ & [22] \\
\hline $\mathrm{k}_{\text {burial }}$ & Burial rate coefficient & $\mathrm{m}_{\text {day }}{ }^{-1}$ & 0.0001 & [23] \\
\hline $\mathrm{k}_{\mathrm{N}}$ & $\begin{array}{l}\text { Half-saturation constant for uptake of } \\
\text { inorganic nitrogen }\end{array}$ & $\operatorname{mg~N~m}{ }^{-3}$ & 28 & [24] \\
\hline $\mathrm{k}_{\text {osdecom }}$ & $\begin{array}{l}\text { Half-saturation constant of oxygen for } \\
\text { decomposition }\end{array}$ & $\mathrm{g} \mathrm{O}_{2} \mathrm{~m}^{-3}$ & 0.5 & [12] \\
\hline $\mathrm{k}_{\text {osnitri }}$ & $\begin{array}{l}\text { Half-saturation constant of oxygen for } \\
\text { nitrification }\end{array}$ & $\mathrm{g} \mathrm{O}_{2} \mathrm{~m}^{-3}$ & 1 & {$[12]$} \\
\hline $\mathrm{k}_{\text {ownitri }}$ & $\begin{array}{l}\text { Half-saturation constant of oxygen for } \\
\text { denitrification }\end{array}$ & $\mathrm{g} \mathrm{O}_{2} \mathrm{~m}^{-3}$ & 2 & [12] \\
\hline$k_{P}$ & $\begin{array}{l}\text { Half-saturation constant for uptake of } \\
\text { inorganic phosphorus }\end{array}$ & $\mathrm{mg} \mathrm{P} \mathrm{m}{ }^{-3}$ & 17 & [25] \\
\hline $\mathrm{ks}_{\mathrm{decomN1}}$ & $\begin{array}{l}\text { Sediment decomposition coefficient from } \\
\text { DETN to } \mathrm{NH}_{4}^{+}\end{array}$ & day $^{-1}$ & 0.07 & [23] \\
\hline $\mathrm{ks}_{\text {decomN2 }}$ & $\begin{array}{l}\text { Sediment decomposition coefficient from } \\
\text { DETN to DON }\end{array}$ & day $^{-1}$ & 0.07 & [23] \\
\hline $\mathrm{ks}_{\text {decomN3 }}$ & $\begin{array}{l}\text { Sediment decomposition coefficient from } \\
\text { DON to } \mathrm{NH}_{4}^{+}\end{array}$ & day $^{-1}$ & 0.9 & Tuning * \\
\hline $\mathrm{ks}_{\mathrm{decomP1}}$ & $\begin{array}{l}\text { Sediment decomposition coefficient from } \\
\text { DETP to DIP }\end{array}$ & day $^{-1}$ & 0.07 & [23] \\
\hline $\mathrm{ks}_{\mathrm{decomP2}}$ & $\begin{array}{l}\text { Sediment decomposition coefficient from } \\
\text { DETP to DOP }\end{array}$ & day $^{-1}$ & 0.07 & [23] \\
\hline $\mathrm{ks}_{\mathrm{decomP3}}$ & $\begin{array}{l}\text { Sediment decomposition coefficient from } \\
\text { DOP to DIP }\end{array}$ & day $^{-1}$ & 0.7 & Tuning * \\
\hline $\mathrm{ks}_{\text {denitri }}$ & Denitrification coefficient in sediment at $0^{\circ} \mathrm{C}$ & day $^{-1}$ & 9 & Tuning * \\
\hline $\mathrm{k}_{\text {sinkDET }}$ & Sinking speed of detritus & $m$ day $^{-1}$ & 0.5 & {$[26]$} \\
\hline $\mathrm{k}_{\text {snitri }}$ & Nitrification coefficient in sediment at $0{ }^{\circ} \mathrm{C}$ & day $^{-1}$ & 7 & Tuning * \\
\hline $\mathrm{kT}$ & Temperature coefficient & ${ }^{\circ} \mathrm{C}^{-1}$ & 0.0693 & {$[27]^{\circ}$} \\
\hline $\mathrm{k}_{\mathrm{wdecomN1}}$ & $\begin{array}{l}\text { Decomposition coefficient from DETN to } \\
\mathrm{NH}_{4}^{+}\end{array}$ & day $^{-1}$ & 0.01 & [28] \\
\hline $\mathrm{k}_{\mathrm{wdecomN} 2}$ & $\begin{array}{l}\text { Decomposition coefficient from DETN to } \\
\mathrm{NH}_{4}^{+}\end{array}$ & day $^{-1}$ & 0.02 & [28] \\
\hline $\mathrm{k}_{\mathrm{wdecomN3}}$ & $\begin{array}{l}\text { Decomposition coefficient from DON to } \\
\mathrm{NH}_{4}^{+}\end{array}$ & day $^{-1}$ & 0.01 & [28] \\
\hline $\mathrm{k}_{\mathrm{wdecomP1}}$ & Decomposition coefficient from DETP to DIP & day $^{-1}$ & 0.02 & {$[28]$} \\
\hline $\mathrm{k}_{\mathrm{wdecomP2}}$ & $\begin{array}{l}\text { Decomposition coefficient from DETP to } \\
\text { DOP }\end{array}$ & day $^{-1}$ & 0.02 & [28] \\
\hline $\mathrm{k}_{\mathrm{wdecomP3}}$ & Decomposition coefficient from DOP to DIP & day $^{-1}$ & 0.02 & [28] \\
\hline $\mathrm{k}_{\mathrm{wdenitri}}$ & Denitrification coefficient in water at $0^{\circ} \mathrm{C}$ & day $^{-1}$ & 0.09 & [12] \\
\hline $\mathrm{k}_{\text {wnitri }}$ & Nitrification coefficient in water at $0^{\circ} \mathrm{C}$ & day $^{-1}$ & 0.08 & [28] \\
\hline 1 & Ivlev's constant & day $^{-1}$ & 0.72 & [28] \\
\hline $\mathrm{NP}_{\text {converter }}$ & Ammonium converter to Phosphorus & & 2.21 & Tuning * \\
\hline $\mathrm{PN}_{\text {converter }}$ & Phosphorus converter to Ammonium & & 0.452 & Tuning * \\
\hline vATR & Volume artificial timber reef & $\mathrm{m}^{-3}$ & 3200 & - \\
\hline$\varphi$ & Porosity of sediment & - & 0.89 & [29] \\
\hline a o/n & Oxygen to nitrogen ratio of organic matter & $\mathrm{g} \mathrm{O} / \mathrm{g} \mathrm{N}$ & 19.71 & [16] \\
\hline
\end{tabular}


Table 1. Cont.

\begin{tabular}{|c|c|c|c|c|}
\hline Symbols & Definitions & Units & Value & Sources \\
\hline $\mathrm{r}$ & Water exchange rate & day $^{-1}$ & 0.4 & [15] \\
\hline Iopt & Optimum light intensity & $\begin{array}{c}\mu \mathrm{E} \mathrm{m^{-2 }} \\
\text { day }^{-1}\end{array}$ & $5.93 \times 10^{7}$ & [26] \\
\hline excOYS & Input from excretion of oyster cultivation & $\underset{\text { day }^{-1}}{\mathrm{mgP} \mathrm{m}^{-3}}$ & 0.012 & [30] \\
\hline faeOYS & Input from egestion of oyster cultivation & $\underset{\text { day }^{-1}}{\mathrm{mgP} \mathrm{m}^{-3}}$ & 0.003 & [30] \\
\hline mortalOYS & Input from mortality of oyster cultivation & $\underset{\text { day }^{-1}}{\mathrm{mgP} \mathrm{m}^{-3}}$ & 0.5 & [30] \\
\hline
\end{tabular}

* Tuning: the parameter is tuned to fit the outputs to the observed data. The parameters are tuned based on the range value reported from several related papers. In addition, the parameters were tuned by slightly increasing or decreasing (in a reasonable range) closer to the reported value from the related paper.

The equations used in the model are described as follows [11], with parameters used from Table 1. Decomposition of DET to dissolved organic matter (DOM); DET to DIP, $\mathrm{NH}_{4}^{+}$; and DOM to DIP, $\mathrm{NH}_{4}^{+}$in the water are expressed in Equations (1)-(3):

$$
\begin{aligned}
& \text { decom }_{\mathrm{W} 1}=\mathrm{k}_{\mathrm{wdecom} 1} \cdot e^{k T \cdot T} \cdot \mathrm{DET} \\
& \text { decom }_{\mathrm{W} 2}=\mathrm{k}_{\mathrm{wdecom} 2} \cdot e^{k T \cdot T} \cdot \mathrm{DET} \\
& \text { decom }_{\mathrm{W} 3}=\mathrm{k}_{\mathrm{wdecom} 3} \cdot e^{k T \cdot T} \cdot \mathrm{DET}
\end{aligned}
$$

Both nitrification and denitrification occurring in the water column are functions of DO, as illustrated in Equations (4) and (5):

$$
\begin{gathered}
\text { nitri }_{\mathrm{W}}=\mathrm{k}_{\mathrm{wnitri}} \cdot e^{k T \cdot T} \cdot\left(\mathrm{DO} /\left(\mathrm{DO}+\mathrm{k}_{\text {onitri }}\right)\right) \cdot \mathrm{NH}_{4}^{+} \\
\text {denitri }_{\mathrm{W}}=\mathrm{k}_{\mathrm{wdenitri}} \cdot e^{k T \cdot T} \cdot\left(1-\left(\mathrm{DO} /\left(\mathrm{DO}+\mathrm{k}_{\text {ownitri }}\right)\right)\right) \cdot \mathrm{NO}_{3}^{-}
\end{gathered}
$$

Sinking of DET from the water column to the sediment is shown in Equation (6):

$$
\sin _{\mathrm{DET}}=\mathrm{k}_{\mathrm{sinkDET}} \cdot \mathrm{DET}
$$

In the benthic system, the decomposition of DET to DOM; DET to DIP and $\mathrm{NH}_{4}^{+}$; and DOM to DIP, $\mathrm{NH}_{4}^{+}$are functions of DO, as shown in Equations (7)-(9):

$$
\begin{aligned}
& \text { decom }_{\mathrm{S} 1}=\mathrm{k}_{\mathrm{sdecom} 1} \cdot e^{k T \cdot T} \cdot\left(\mathrm{DO} /\left(\mathrm{DO}+\mathrm{k}_{\mathrm{osdecom}}\right)\right) \cdot \mathrm{DET} \\
& \operatorname{decom}_{\mathrm{S} 2}=\mathrm{k}_{\mathrm{sdecom} 2} \cdot e^{k T \cdot T} \cdot\left(\mathrm{DO} /\left(\mathrm{DO}+\mathrm{k}_{\mathrm{osdecom}}\right)\right) \cdot \mathrm{DET} \\
& \operatorname{decom}_{\mathrm{S} 3}=\mathrm{k}_{\mathrm{sdecom} 3} \cdot e^{k T \cdot T} \cdot\left(\mathrm{DO} /\left(\mathrm{DO}+\mathrm{k}_{\mathrm{osdecom}}\right)\right) \cdot \mathrm{DET}
\end{aligned}
$$

For the nitrification and denitrification occurring in the sediment, we used similar forms of equations, as shown in Equations (10) and (11):

$$
\begin{gathered}
\operatorname{nitri}_{\mathrm{s}}=\mathrm{k}_{\text {snitri }} \cdot\left(\mathrm{DO} /\left[\mathrm{DO}+\mathrm{k}_{\mathrm{osnitri}}\right]\right) \cdot \mathrm{NH}_{4}^{+} \\
\text {denitri }_{\mathrm{s}}=\mathrm{k}_{\text {sdenitri }} \cdot \mathrm{e}^{k T \cdot T} \cdot\left(1-\left(\mathrm{DO} /\left[\mathrm{DO}+\mathrm{k}_{\mathrm{osnitri}}\right]\right)\right) \cdot \mathrm{NO}_{3}^{-}
\end{gathered}
$$

Furthermore, the burial of DET to the deeper sediment layers is shown in Equation (12):

$$
\text { burial }=\mathrm{k}_{\text {burial }} \cdot \mathrm{DET}, \mathrm{DOM}, \mathrm{DIP}, \mathrm{NH}_{4}^{+}, \mathrm{NO}_{3}^{-}
$$


Diffusion of DOM, DIP, $\mathrm{NH}_{4}^{+}, \mathrm{NO}_{3}^{-}$at the sediment-water interface is shown in Equation (13):

$$
\mathrm{C}_{\mathrm{DIF}}=2 \cdot \varphi \cdot \mathrm{D}_{c}^{\prime}\left(\mathrm{C}_{\mathrm{DET}}-\mathrm{C}_{\mathrm{W}}\right)
$$

The loss of DIP, $\mathrm{NH}_{4}^{+}$, and $\mathrm{NO}_{3}^{-}$through uptake by phytoplankton (PHY), microalgae (MIA), macroalge (MAA), and benthic microalgae $\left(\mathrm{MIA}_{\mathrm{b}}\right)$ is represented in Equation (14):

$$
\begin{gathered}
\text { uptake }_{(\mathrm{PHY}, \mathrm{MIA}, \mathrm{MAA}, \mathrm{MIAb})}=\mu_{\max (\mathrm{PHY}, \mathrm{MIA}, \mathrm{MAA}, \mathrm{MIAb})} \cdot \mathrm{e}^{k T \cdot T} \cdot \mathrm{MIN}\left[\left(\mathrm{NH}_{4}^{+}+\mathrm{NO}_{3}^{-}\right) / \mathrm{NH}_{4}^{+}+\mathrm{NO}_{3}^{-}+\mathrm{k}_{\mathrm{N}}\right) \\
\text { DIP } \left./\left(\mathrm{DIP}+\mathrm{k}_{\mathrm{P}}\right)\right] \cdot \mathrm{I} / \mathrm{I}_{\mathrm{opt}} \exp \left(1-\left(\mathrm{I} / \mathrm{I}_{\mathrm{opt}}\right)\right) \cdot\left(\mathrm{PHY}, \mathrm{MIA}, \mathrm{MAA}, \mathrm{MIA}_{\mathrm{b}}\right)
\end{gathered}
$$

Exchange of DIP, $\mathrm{NH}_{4}^{+}$, and $\mathrm{NO}_{3}^{-}$between ATRs and $\mathrm{MB}$ is calculated using Equations (15)-(17):):

$$
\begin{aligned}
\text { DIPexch } & =\mathrm{r} \cdot(\text { DIP_ATRs }- \text { DIP_MB }) \\
\mathrm{NH}_{4}^{+} \text {exch } & =\mathrm{r} \cdot\left(\mathrm{NH}_{4}^{+} \text {-ATRs }-\mathrm{NH}_{4}^{+} \_\mathrm{MB}\right) \\
\mathrm{NO}_{3}^{-} \text {exch } & =\mathrm{r} \cdot\left(\mathrm{NO}_{3}^{-} \text {ATRs }-\mathrm{NO}_{3}^{-} \mathrm{MB}\right)
\end{aligned}
$$

The inputs of excretion (excOYS), egestion (faeOYS), and mortality (mortalOYS) from oyster cultivation in $\mathrm{MB}$ were obtained by comparing the oyster production in the area with those in Hiroshima Bay [30] (Table 1).

The numerical model was developed using STELLA Architect v1.6.0 (https://www.iseesystems. com). We ran the model for 1020 days with a time step of $0.36 \mathrm{~h}$. The calculations were performed using the fourth-order Runge-Kutta method. The outputs were compared with the values obtained from field observations [20] and the accuracy of validation was evaluated with the percent bias (PBIAS). PBIAS is a measure of over- and under-estimation of bias for predicted and measured values, and is expressed as a percentage [31]. The performance rating in fitting of the model output to the observed value was evaluated with the following criteria [32]: very good $(< \pm 25 \%)$, good ( \pm 25 PBIAS $< \pm 40$ ), satisfactory $( \pm 40$ PBIAS $< \pm 70)$, and non-satisfactory $(\geq \pm 71)$.

\section{Results}

\subsection{Reproducibility of Calculation Outputs to the Observed Seasonal Variations}

The calculated concentrations of DIP, $\mathrm{NH}_{4}^{+}$, and $\mathrm{NO}_{3}^{-}$nutrients in the ATR deployment area and $\mathrm{MB}$ are illustrated in Figure 3. In the ATR deployment area, the calculated DIP and $\mathrm{NO}_{3}^{-}$concentrations were consistent with the observed values, which were generally high in autumn and winter, and low in spring and summer. According to the PBIAS values, the calculation outputs for DIP were "very good," with a value of $5 \%$. Conversely, the calculated $\mathrm{NH}_{4}^{+}$and $\mathrm{NO}_{3}^{-}$concentrations were judged "good," with PBIAS values of $-67 \%$ and $-26 \%$, respectively. The calculated DIP, $\mathrm{NH}_{4}^{+}$, and $\mathrm{NO}_{3}^{-}$concentrations in the ATR deployment area were approximately two-fold higher than the concentrations in the water in MB. The seasonal trends of the nutrients in the MB area, which were high in autumn and winter, and low in spring and summer, were similar to the trends observed in the ATR area. The observed values of nutrient concentrations outside of the bay (boundary) seem to be higher than the calculated concentrations in the bay. 


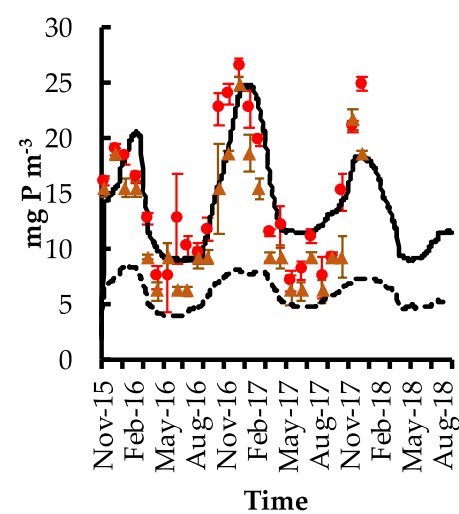

(a)

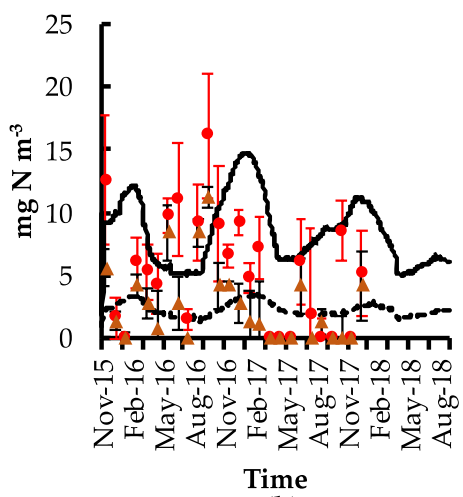

(b)

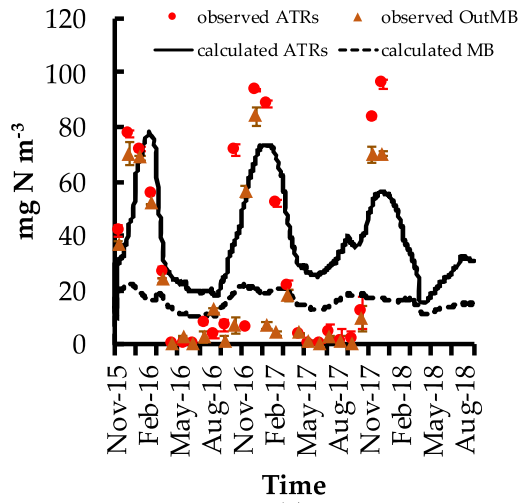

(c)

Figure 3. Seasonal changes in (a) dissolved inorganic phosphorus (DIP), (b) ammonium $\left(\mathrm{NH}_{4}^{+}\right)$and (c) nitrate $\left(\mathrm{NO}_{3}^{-}\right)$concentrations in the artificial timber reef (ATR)-deployed areas and in the Mitsu Bay (MB). The red-filled circles show the observed ATRs, the solid lines show the calculated ATRs, th ebrown-filled triangles show the values observed outside the MB and the black broken lines show the calculated MB values.

The calculated DET-P concentrations in the water column of the ATR areas exhibited trends similar to DIP with high values in winter and low values in summer (Figure 4). Although the trends seem unclear in the DOP stock, the DON concentrations were consistent in seasonality with DET-N, with approximately half of the DET-N concentrations.

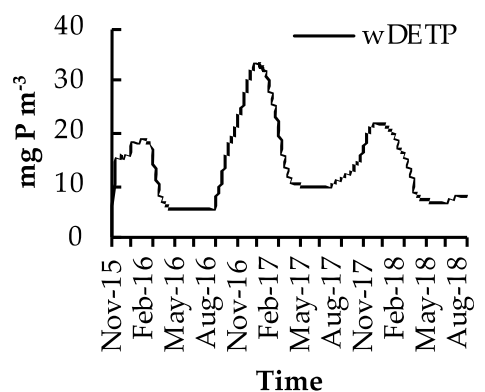

(a)

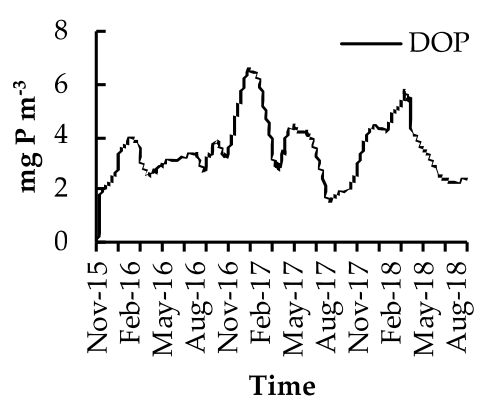

(c)

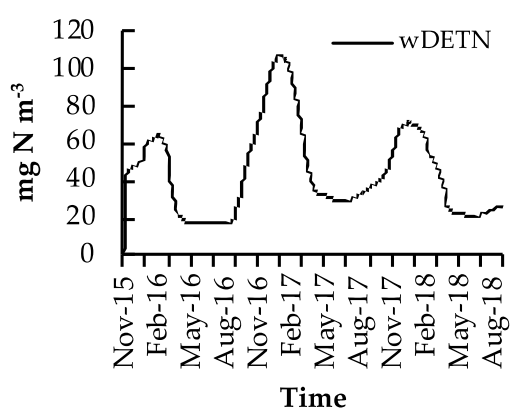

(b)

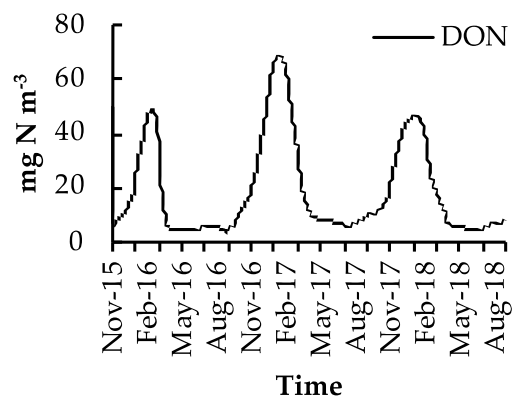

(d)

Figure 4. Seasonal changes in the calculated (a) detritus-P (waterDET-P), (b) detritus N (waterDET-N), (c) dissolved organic $\mathrm{P}(\mathrm{DOP})$, and (d) dissolved organic $\mathrm{N}(\mathrm{DON})$ in the ATR-deployed area.

The calculated $\mathrm{P}$ and $\mathrm{N}$ concentrations in the sediment are illustrated in Figure 5. The calculated DET-P and DET-N were high in summer and low in winter, respectively. Such trends were also observed in DOP and DON. The seasonal DIP, $\mathrm{NH}_{4}^{+}$, and $\mathrm{NO}_{3}^{-}$trends in the sediment pore water were similar to those in the pelagic system, being higher in winter and lower in summer. 


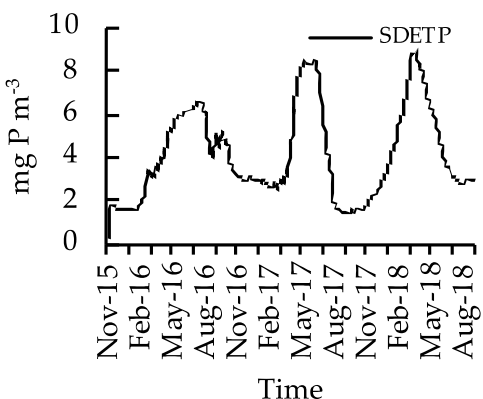

(a)

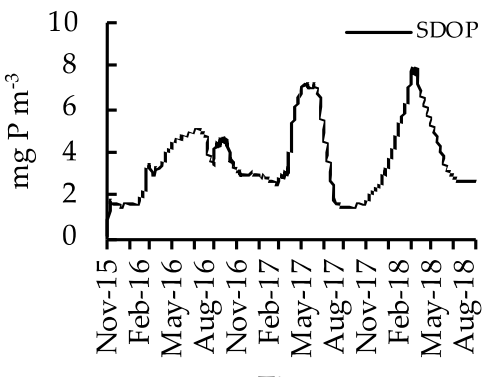

(c)

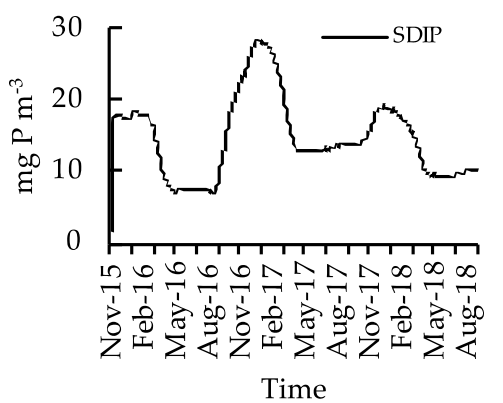

(e)

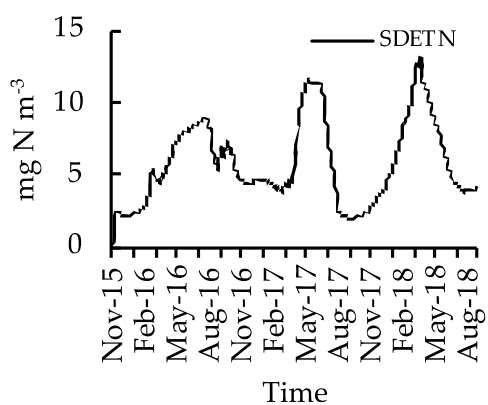

(b)

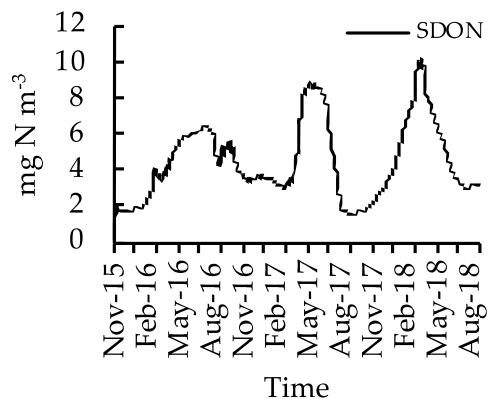

(d)

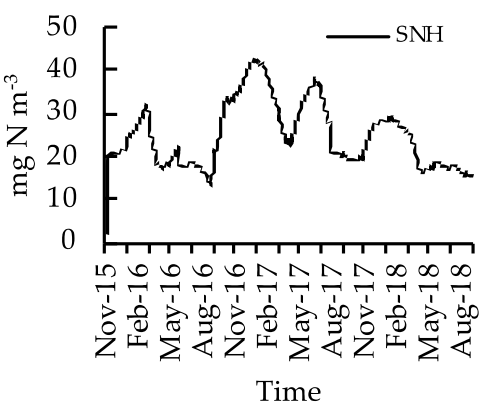

$(\mathbf{f})$

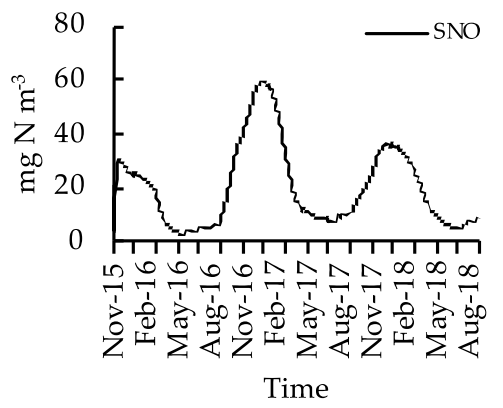

(g)

Figure 5. Seasonal changes in the estimated nutrients: (a) sediment detritus-P (sedimentDET-P); (b) sediment detritus-N (sedimentDET-N); (c) sediment dissolved organic P (SDOP); (d) sediment dissolved organic N (SDON); (e) sediment dissolved inorganic P (SDIP); (f) sediment ammonium $(\mathrm{SNH}) ;$ and $(\mathrm{g})$ sediment nitrate $(\mathrm{SNO})$ in the benthic system of the ATR-deployed area.

\subsection{Balances in Inputs and Outputs}

The inputs to and outputs from DIP, $\mathrm{NH}_{4}^{+}$, and $\mathrm{NO}_{3}^{-}$stocks in the ATR area and the MB area are presented in Table 2. In the ATR area, the major inputs to the DIP stock were organism excretions $(27 \%)$, followed by decomposition processes $(11 \%)$. Conversely, the major outputs from the DIP stock were the phytoplankton uptake (35\%) and physical transport to the surrounding water via water exchange (16\%). With regard to $\mathrm{NH}_{4}^{+}$, organism excretions (24\%) was also the highest contributor to the stock. 
In addition to organism excretions, the contribution of benthic flux was high (20\%). Nitrification, the process of oxidation of ammonium into nitrate, was the major pathway for the decrease in $\mathrm{NH}_{4}^{+}$ concentration, accounting for $42 \%$. Other outputs, including phytoplankton uptake (7\%) and transport to the surrounding water $(3.3 \%)$, were also pathways of reduction of $\mathrm{NH}_{4}^{+}$concentrations. Nitrification was a major pathway of the increase in $\mathrm{NO}_{3}^{-}$stock, accounting for $37 \%$. For the loss of $\mathrm{NO}_{3}^{-}$stock, uptake by producers accounted for $31 \%$ and $12 \%$ was attributed to denitrification.

The major inputs to DIP in the MB area were transport from the ATR areas $(25 \%)$, transport from outside the $\mathrm{MB}(13 \%)$, and excretion by organisms (11\%). Other sources such as input from rivers, sewage discharge, precipitation, and benthic flux were very low ( $<1 \%$ in total). With regard to DIP outputs, phytoplankton uptake represented the greatest pathway (35\%). In the case of $\mathrm{NH}_{4}^{+}$, the major input to the MB water was excretion (32\%), although the rate was two times lower in the MB water, while the highest output was the nitrification process (33\%). In the case of $\mathrm{NO}_{3}^{-}$in $\mathrm{MB}$, the major input was transport from the ATR areas (23\%). Other inputs were nitrification from ammonium and transport from outside of the MB area, which accounted for $16 \%$ and $11 \%$, respectively. In addition, the major $\mathrm{NO}_{3}^{-}$outputs were phytoplankton uptake (23\%) and transport to the ATR areas (14\%).

Table 2. Inflow and outflow rates of various processes $\left(\mathrm{mg} \mathrm{m}^{-3} \mathrm{day}^{-1}\right)$ and their contributions (\%) to nutrient stocks. Minus sign (-) indicates nutrient outflow from the standing stock.

\begin{tabular}{|c|c|c|c|c|}
\hline \multirow{2}{*}{ Processes } & \multicolumn{2}{|l|}{ ATRs } & \multicolumn{2}{|c|}{ Mitsu Bay } \\
\hline & $\mathrm{mg} \mathrm{m}^{-3}$ day $^{-1}$ & $\%$ & $\mathrm{mg} \mathrm{m}^{-3}$ day $^{-1}$ & $\%$ \\
\hline DIP & & & 0.002 & $<0.1$ \\
\hline Sewage load & & & 0.002 & $<0.1$ \\
\hline Precipitation & 0.004 & $<0.1$ & 0.004 & $<0.1$ \\
\hline Transport from southern part of Mitsu Bay & & & 3.1 & 13 \\
\hline Transport from ATRs area & -6.2 & -16 & 6.2 & 25 \\
\hline Benthic flux & 1.7 & 4.3 & 0.4 & 1.6 \\
\hline Decomposition & 4.3 & 11 & 0.4 & 1.7 \\
\hline Excretion & 10.6 & 27 & 2.7 & 11 \\
\hline Producers uptake & -13.6 & -35 & -6.3 & -26 \\
\hline Transport to southern part of Mitsu Bay & & & -2.3 & -9 \\
\hline Transport to ATRs area & 3.0 & 7.6 & -3.0 & -12 \\
\hline \multicolumn{5}{|l|}{$\mathrm{NH}_{4}^{+}$} \\
\hline Riverine load & & & 0.01 & $<0.1$ \\
\hline Sewage load & & & 0.003 & $<0.1$ \\
\hline Precipitation & 0.1 & 0.1 & 0.1 & 0.3 \\
\hline Transport from southern part of Mitsu Bay & & & 1.4 & 4.2 \\
\hline Transport from ATRs area & -3.9 & -3.3 & 3.9 & 12 \\
\hline Benthic flux & 24.4 & 20 & 0.4 & 1.2 \\
\hline Decomposition & 3.4 & 2.8 & 1.0 & 2.9 \\
\hline Excretion & 28.3 & 24 & 10.8 & 32 \\
\hline Producers uptake & -8.4 & -7 & -2.4 & -7.2 \\
\hline Transport to southern part of Mitsu Bay & & & -0.8 & -2.4 \\
\hline Transport to ATRs area & 1.4 & 1.2 & -1.4 & -4.2 \\
\hline Nitrification & -49.7 & -42 & -11.1 & -33 \\
\hline \multicolumn{5}{|l|}{$\mathrm{NO}_{3}^{-}$} \\
\hline Riverine load & & & 0.03 & $<0.1$ \\
\hline Sewage load & & & 0.01 & $<0.1$ \\
\hline Precipitation & 0.06 & $<0.1$ & 0.06 & $<0.1$ \\
\hline Transport from southern part of Mitsu Bay & & & 7.9 & 11 \\
\hline Transport from ATRs area & -16.2 & -13 & 16.2 & 23 \\
\hline Benthic flux & 0.4 & 0.3 & 0.4 & 0.5 \\
\hline
\end{tabular}


Table 2. Cont.

\begin{tabular}{|c|c|c|c|c|}
\hline \multirow{2}{*}{ Processes } & \multicolumn{2}{|c|}{ ATRs } & \multicolumn{2}{|c|}{ Mitsu Bay } \\
\hline & $\mathrm{mg} \mathrm{m}^{-3}$ day $^{-1}$ & $\%$ & $\mathrm{mg} \mathrm{m}^{-3} \mathrm{day}^{-1}$ & $\%$ \\
\hline Producers uptake & -38.6 & -31 & -16.0 & -23 \\
\hline Transport to southern part of Mitsu Bay & & & -4.1 & -5.8 \\
\hline Transport to ATRs area & 9.6 & 7.7 & -9.6 & -14 \\
\hline Nitrification & 45.7 & 37 & 11.2 & 16 \\
\hline Denitrification & -14.8 & -12 & -5.6 & -8 \\
\hline
\end{tabular}

\subsection{Internal Regeneration}

Internal regeneration was the major source of $\mathrm{P}$ and $\mathrm{N}$ inputs in both the ATR systems and the MB area (Figures 6 and 7). In the ATR area, internal regeneration accounted for $0.04 \mathrm{~kg} \mathrm{P}$ day $^{-1}(14.9 \mathrm{mg}$ $\mathrm{P} \mathrm{m}^{-3}$ day $\left.^{-1}\right)$, while in $\mathrm{MB}$, it accounted for $449 \mathrm{~kg} \mathrm{P} \mathrm{day}^{-1}\left(3.1 \mathrm{mg} \mathrm{P} \mathrm{m}^{-3} \mathrm{day}^{-1}\right)$. In the case of $\mathrm{N}$, internal regeneration accounted for $0.1 \mathrm{~kg} \mathrm{~N}$ day $^{-1}\left(31.7 \mathrm{mg} \mathrm{N} \mathrm{m}^{-3}\right.$ day $\left.^{-1}\right)$ in the ATR area and $1695 \mathrm{~kg} \mathrm{~N}$ day $^{-1}\left(11.8 \mathrm{mg} \mathrm{N} \mathrm{m}^{-3}\right.$ day $\left.^{-1}\right)$ in MB. The ATR area was a source of $\mathrm{P}, \mathrm{NH}_{4}^{+}$, and $\mathrm{NO}_{3}^{-}$for $\mathrm{MB}$, at $0.01 \mathrm{~kg} \mathrm{P}$ day $^{-1}, 0.01 \mathrm{~kg} \mathrm{~N}$ day $^{-1}$, and $0.05 \mathrm{~kg} \mathrm{~N}$ day $^{-1}$, respectively.

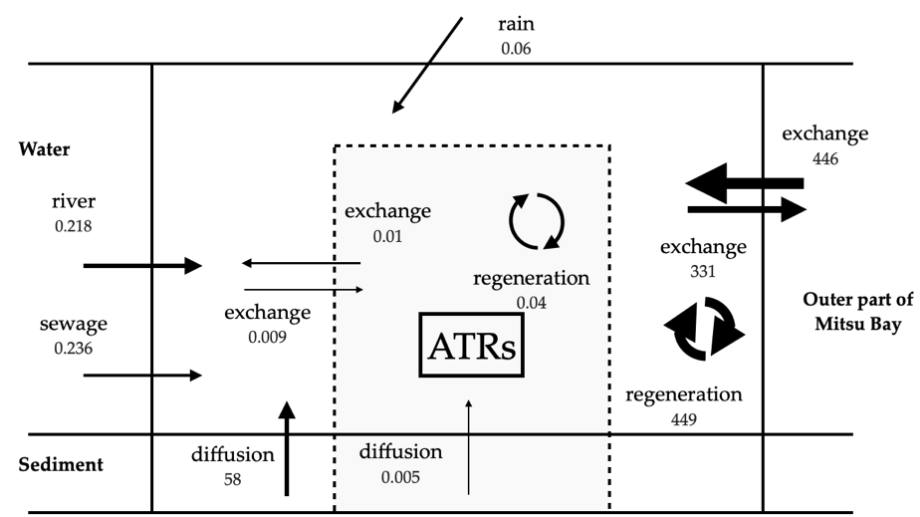

Figure 6. Annual average phosphorus flows $\left(\mathrm{kg} \mathrm{P} \mathrm{day}^{-1}\right)$ from various sources in the ATR areas $\left(\mathrm{V}: 3200 \mathrm{~m}^{-3}\right.$ ) and in Mitsu Bay (V: 144,000,000 $\mathrm{m}^{-3}$ ). Arrow thickness represents their contributions (Thick arrow: $>10 \mathrm{~kg} \mathrm{P}$ day $^{-1}$, moderate arrow: 0.1-10 $\mathrm{kg} \mathrm{P}$ day $^{-1}$. thin arrow: 0-0.1 $\mathrm{kg} \mathrm{P} \mathrm{day}^{-1}$ ). The square indicating the imaginal demarcation between the ATR area and Mitsu Bay.

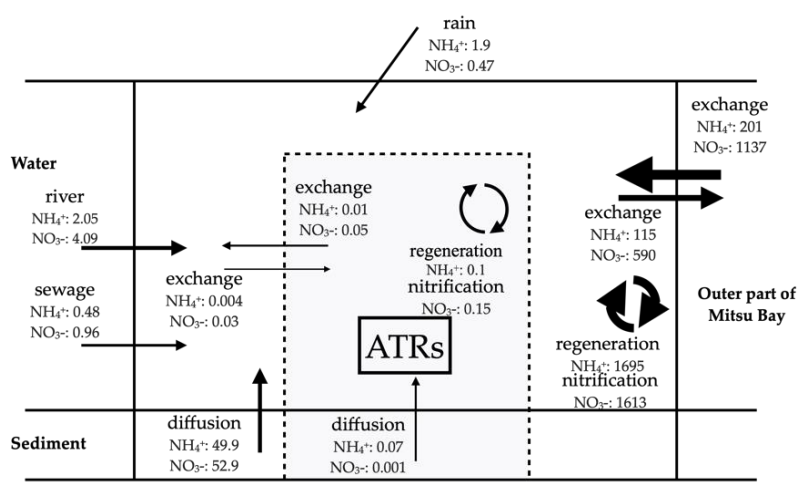

Figure 7. Annual average nitrogen flows $\left(\mathrm{kg} \mathrm{N}\right.$ day $\left.^{-1}\right)$ from various sources in the ATR areas (V:3200 $\mathrm{m}^{-3}$ ) and in Mitsu Bay (V: 144,000,000 $\mathrm{m}^{-3}$ ). Arrow size reflects their contributions, where thicker arrows indicate major pathways (Thick arrow: $>10 \mathrm{~kg} \mathrm{P} \mathrm{day}^{-1}$, moderate arrow: $0.1-10 \mathrm{~kg} \mathrm{P}$ day $^{-1}$. thin arrow: $0-0.1 \mathrm{~kg} \mathrm{P} \mathrm{day}^{-1}$ ). The dotted square indicates the imaginary demarcation between the ATR areas and Mitsu Bay. 


\section{Discussion}

\subsection{Seasonal Variation in Nutrient Concentrations and the Potential Causes}

The dissolved inorganic forms of $\mathrm{P}$ and $\mathrm{N}$, such as $\mathrm{DIP}, \mathrm{NH}_{4}^{+}$, and $\mathrm{NO}_{3}^{-}$, which are referred to as "nutrients", are required by marine algae for their growth and they regulate primary production in the seas [33]. The calculated nutrient concentrations in the ATR pelagic system were consistent with the observed values, with similar seasonal trends, being high in autumn and winter, and low in spring and summer (Figure 3). These seasonal trends were also similar to the results observed in Hiroshima Bay, which is next to MB [11], and to results reported in artificial reefs in southern Portugal [33]. As represented in Table 2, the major causes of increase in DIP and $\mathrm{NH}_{4}^{+}$in the pelagic system were excretion by organisms, whose biomass peaked in winter.

The calculated concentrations of DOP, DON, DET-P, and DET-N stocks in the ATRs were in the range of those in Hiroshima Bay, which is a more eutrophicated bay than MB, and is located approximately $50 \mathrm{~km}$ west of $\mathrm{MB}$ [11]. Among these parameters, the calculated average concentrations of DET-P and DET-N in MB were higher than those reported for Hiroshima Bay. They were $14 \mathrm{mg} \mathrm{P} \mathrm{m}^{-3}$ and $44 \mathrm{mg} \mathrm{N} \mathrm{m}^{-3}$, compared to approximately $7 \mathrm{mg} \mathrm{P} \mathrm{m}^{-3}$ and $40 \mathrm{mg} \mathrm{N} \mathrm{m}^{-3}$ for DET-P and DET-N, respectively, in Hiroshima Bay.

The nutrient concentrations in MB were lower than those in the ATR areas and those outside the bay. The nutrient concentrations outside the bay used as the boundary conditions for MB were not as low as the concentrations in the MB areas (Figure 3). The average data were taken from three layers in the water column, at 0,5 , and $1 \mathrm{~m}$ above the bottom. Regarding the bottom topography, it goes deeper probably sharply at the mouth of the bay. The outside of the bay, which had a deeper layer, had potentially higher concentrations when compared to the relatively shallow MB. Deeper layers often have higher nutrient concentrations as a result of the decomposition of organic matter. Another factor is the cooling of the water column in winter. The overturning of the water column in the cooler season is another cause of increase in nutrient concentration, as observed in the larger gap during winter in the observed data outside of MB.

\subsection{Internal Regeneration of Nutrients in the ATR Deployment Area}

Higher nutrient concentrations were estimated in the ATR area compared to the waters in MB. In the ATRs, internal nutrient regeneration was the major process compared to the other sources. In the entire $\mathrm{MB}$, the internal regeneration also played a key role as a major source of nutrient input when compared to the relatively low inputs of other sources such as river inflows, sewerage, etc., (Table 2). As shown in Table 2, the internal regeneration contributed considerably to the bay primary production. In the ATR system, the biomass of organisms and fish was high compared to those in the surrounding area. As they produce organic matter as feces, urine, and sometimes dead matter, such organic matter becomes nutrient supply sources, which are utilized by algae again [34]. The estimates summarized in Table 2 show that the DIP and $\mathrm{NH}_{4}^{+}$inputs from excretion in the ATR areas were two to three times higher than the inputs in MB.

ATRs also increase biodeposits, which are not only feces but also dead attached animal bodies peeled off from the ATRs. The deposition rate was calculated to be $47.7 \mathrm{mg} \mathrm{P} \mathrm{m}^{-3} \mathrm{day}^{-1}$ and $62.6 \mathrm{mg} \mathrm{N} \mathrm{m}^{-3}$ day $^{-1}$ for $\mathrm{P}$ and $\mathrm{N}$, respectively. The deposition, in turn, increases the organic matter load to the bottom, and can lead the anoxic sediment status and reduced quality status overall [8]. Enhanced deposition to the benthic systems was also observed in an AR study in southern Portugal [35]. The materials used in the present study, including timber, branches, and leaves, are also sources of organic matter. Such materials decay following degradation by ship worms or the effects of physical activities such as wake waves, which were observed by divers during the observations in the third year after ATR deployment. Overall, the deployment of ATRs had positive effects by serving as sources of nutrients both through increases in the associated organisms on the surfaces of ATRs and the gathering of fish at the sites to feed and hide among the frames and structures. 


\subsection{Denitrification}

Denitrification is a major pathway through which nitrogen is removed from a system, and it often occurs in surface anoxic sediment under nitrate supply. The N2 removed in this process was released to the air through the water surface. The sediment quality in MB is partially anoxic due to feces and pseudofeces loads from intensive oyster aquacultures in the area [15]. As calculated in the present study, $14.8 \mathrm{mg} \mathrm{N} \mathrm{m}^{-2}$ day $^{-1}$ or approximately $0.04 \mathrm{~kg} \mathrm{~N} \mathrm{day}^{-1}$ was removed in the ATR area through denitrification, while $5.6 \mathrm{mg} \mathrm{N} \mathrm{m}^{-2}$ day $^{-1}$ was removed in the $\mathrm{MB}$ area (Table 2). Compared to the increase in feces sedimentation, the removal of $\mathrm{N}$ by denitrification was up to $12 \%$ in ATRs and $8 \%$ in MB. The denitrification rate estimated in the present study was in the range reported in previous studies, including at $4.2-5.88 \mathrm{mg} \mathrm{N} \mathrm{m}^{-2}$ day $^{-1}$ [11] and $0.0-23.2 \mathrm{mg} \mathrm{N} \mathrm{m}^{-2}$ day $^{-1}$ [36], which was reported in studies conducted in Hiroshima Bay, which is adjacent to MB. The range reported in the present study was also within the range reported in Kansas, United States $\left(0-35 \mathrm{mg} \mathrm{N} \mathrm{m}^{-2}\right.$ day $\left.^{-1}\right)$ [37], and that reported in an estuary in Portugal (2-84 $\mathrm{mg} \mathrm{N} \mathrm{m}^{-2}$ day $\left.^{-1}\right)$ [38]. Therefore, denitrification can alleviate the deterioration of sediment quality below the ATRs. However, $\mathrm{P}$ would definitely be accumulated in the sediment.

\subsection{Potential Oligotrophication Countermeasures}

Our model reveals that ATRs function as a source of nutrients for the surrounding water (Table 2). Because other nutrient sources such as inputs from land, precipitation, and benthic flux are quite low, the nutrient regeneration in the ATR area is considered an important nutrient source for MB. This means that ATRs could be one of the promising ways for increasing fish production in an oligotrophic bay such as MB.

In the Seto Inland Sea, cultural oligotrophication is widespread due to the strict implementation of reduction measures for nutrient loads from land as mentioned in the introduction. In several prefectures facing the Seto Inland Sea, sewer discharge regulations have been relaxed. For example, Hyogo Prefecture began relaxing sewer discharge regulations more than five years ago, and they set the target levels of $\mathrm{N}$ and $\mathrm{P}$ nutrient concentrations in seawater required for the maintenance of the local fisheries represented by Nori farming and sand eel [39]. Hiroshima Prefecture, in which MB is found, has initiated discussions on the measures of counteracting the oligotrophication of the coastal seas. However, they are very careful about relaxing sewer operation regulations, because they could inadvertently generate phytoplankton blooms.

In addition, the deployment of ATRs, as demonstrated in the present study, can be a superior strategy for addressing oligotrophication to the relaxation of sewerage disposal regulations. No net increase in nutrient loads have been observed from out of the system in the case of the deployment of timber reefs, which would otherwise be observed following sewage discharge. To implement either of the measures or both, their effects on the alleviation of oligotrophication need to be evaluated based on scientific analyses. Currently, Higashi-Hiroshima City is exploring strategies for increasing fish production in the future, and the optimal strategy could involve a mixture of the two approaches, based on the results of quantitative scientific evaluations. We believe that the results of the present study provide a scientific basis for decision-making by the stakeholders in Higashi-Hiroshima City.

\section{Conclusions}

Our model demonstrates that the deployment of ATRs could enhance the internal regeneration of nutrients ( $\mathrm{DIP}, \mathrm{NH}_{4}^{+}$, and $\mathrm{NO}_{3}^{-}$) in ATR areas by increasing physiological activities, as exemplified by the excretion and feces production by the associated biological communities, including fish. ATRs, by transporting nutrients to the surrounding water, could also be an important local nutrient source in the oligotrophic area. In several neighboring provinces, local authorities have begun relaxing sewer discharge regulations. In Hiroshima Prefecture, the local government is also planning to allow the discharge of sewer into the marine ecosystem. The model we developed in the present study can guide 
administrators to select appropriate measures of increasing productivity in fisheries. In conclusion, the deployment of ATRs is a potential measure of increasing fish production, by accelerating nutrient cycling without any extra external nutrient inputs. In addition, it facilitates the establishment of a recycling-oriented society, in the case of Higashi-Hiroshima City, which has large forest areas that need to be maintained.

Supplementary Materials: The following are available online at http://www.mdpi.com/2073-4441/12/9/2515/s1, Figure S1: Photograph of ARs construction made of thinning timbers. Figure S2: Illustration of food webs in ATRs system (red square) and P and $\mathrm{N}$ cycles in the ATR area. Subscripts and abbreviations: micro algae (MIA), macro algae (MAA), benthic micro algae (MIAb), zooplankton (ZOO), shrimp (SHR), bivalves (BIV), benthic bivalves (BIVb), sedentary worm (SWO), benthic sedentary wom (SWOb), errant worm (EWO), bryozoan (BRY), sea squirt (SSQ), gammarid (GAM), caprellid (CAP), other amphipods (OAM), black seabream Acanthopagrus schlegelii (BSE), black rockfish Sebastes inermis (BRO), Japanese surfperch Ditrema temmincki (JSU), Multicolorfin rainbowfish Parajulis poecilopterus (MRA), Black scraper Thamnaconus modestus (BSC) and Red seabream Pagrus major (RSE), grazing (graz), nutrient uptake (uptake), total feed on prey biomass (feed), natural mortality (mortal), excretion (exc), egestion (fae), biomass eaten by others predation (eat), fishermen catch (catch). Table S1: Standard setting for model runs.

Author Contributions: Conceptualization, J.F.A. and T.Y.; methodology, J.F.A., T.Y. and T.U.; validation, J.F.A.; formal analysis, J.F.A.; investigation, S.N. and K.H.; data curation, T.U., S.N. and K.H.; writing-original draft preparation, J.F.A.; writing-review and editing, T.Y.; supervision, T.Y. and T.U.; project administration, T.Y.; funding acquisition, S.N. and K.H. All authors have read and agreed to the published version of the manuscript.

Funding: This research was funded by Cabinet Office, Government of Japan through its Regional Revitalization and Local Residents Life, Emergency Assistance Grant (Local Creation Proactive) 2015 program and the Program for Investigation of Fish Species Gathering on Artificial Timber Reefs for 2016-2018 by Higashi-Hiroshima City. Jamaluddin Fitrah Alam was supported by Lembaga Pengelola Dana Penelitian (Indonesia Endowment Fund for Education) (LPDP) Doctoral Degree Scholarship (contract no. PRJ-3186/LPDP.3/2016).

Acknowledgments: The authors want to thank the students of Aquatic Environmental Management for the constructive inputs during the development of the model. We would also like to acknowledge Al Furkan for editing the map on this manuscript. We are also thankful to three anonymous reviewers whose suggestions helped improve the manuscript.

Conflicts of Interest: The authors declare no conflict of interest.

\section{References}

1. Yamamoto, T. The Seto Inland Sea-Eutrophic or oligotrophic? Mar. Pollut. Bull. 2003, 47, 37-42. [CrossRef]

2. Yamamoto, T.; Takahashi, S.; Saito, H.; Tanimoto, T. Designing an effective action plan for sustainable local resources and the coastal environment: A case study of Mitsu Bay, Hiroshima, Japan. In Proceedings of the EMECS 11-Sea Coasts XXVI. Joint Conference, St. Petersburg, Russia, 22-27 August 2016; International EMECS Center: Kobe, Japan, 2016; p. 238.

3. Report on the Project to Investigate Fish Production by Settling Artificial Timber Reefs in Mitsu Bay; Higashi-Hiroshima City: Higashi-Hiroshima, Japan, 2016; p. 34. (FY2015) (In Japanese)

4. Report on the Project to Investigate Fish Production by Settling Artificial Timber Reefs in Mitsu Bay; Higashi-Hiroshima City: Higashi-Hiroshima, Japan, 2017; p. 43. (FY2016) (In Japanese)

5. Report on the Project to Investigate Fish Production by Settling Artificial Timber Reefs in Mitsu Bay; Higashi-Hiroshima City: Higashi-Hiroshima, Japan, 2018; p. 52. (FY2017) (In Japanese)

6. Report on the Project to Investigate Fish Production by Settling Artificial Timber Reefs in Mitsu Bay; Higashi-Hiroshima City: Higashi-Hiroshima, Japan, 2019; p. 48. (FY2018) (In Japanese)

7. Alam, J.F.; Yamamoto, T.; Umino, T.; Nakahara, S.; Hiraoka, K. Diversity of Attached Marine Life in Different Types of Artificial Timber Reefs. In Proceedings of the the 2nd International Symposium on Marine Science and Fisheries (ISMF2), Makassar, Indonesia, 22 June 2019; IOP Publishing: Bristol, UK, 2019; Volume 370, p. 012034.

8. Ambrose, R.F.; Anderson, T.W. Influence of an artificial reef on the surrounding infaunal community. Mar. Biol. 1990, 107, 41-52. [CrossRef]

9. Falcão, M.; Santos, M.N.; Vicente, M.; Monteiro, C.C. Biogeochemical processes and nutrient cycling within an artificial reef off Southern Portugal. Mar. Environ. Res. 2007, 63, 429-444. [CrossRef] 
10. Yanagi, T. Numerical ecosystem model of phosphorus and nitrogen cycling in Tokyo Bay. Oceanogr. Jpn. 2004, 13, 61-72. [CrossRef]

11. Kittiwanich, J.; Yamamoto, T.; Kawaguchi, O.; Hashimoto, T. Analyses of phosphorus and nitrogen cyclings in the estuarine ecosystem of Hiroshima Bay by a pelagic and benthic coupled model. Estuar. Coast Shelf Sci. 2007, 75, 189-204. [CrossRef]

12. Chapelle, A.; Ménesguen, A.; Deslous-Paoli, J.M.; Souchu, P.; Mazouni, N.; Vaquer, A.; Millet, B. Modelling nitrogen, primary production and oxygen in a Mediterranean lagoon. Impact of oysters farming and inputs from the watershed. Ecol. Modell. 2000, 127, 161-181. [CrossRef]

13. Friedland, R.; Buer, A.-L.; Dahlke, S.; Schernewski, G. Spatial effects of different zebra mussel farming strategies in an Eutrophic Baltic Lagoon. Front. Environ. Sci. 2019, 6, 158. [CrossRef]

14. Bristow, L.A.; Mohr, W.; Ahmerkamp, S.; Kuypers, M.M. Nutrients that limit growth in the ocean. Curr. Biol. 2017, 27, R474-R478. [CrossRef]

15. IDEA Consultants Inc. Report on the Project to Improve Material Cycle in the Sea to Healthy Condition; The commissioned project by Ministry of the Environment, Japan; IDEA Consultants Inc.: Tokyo, Japan, 2013; p. 192, (In Japanese with English Abstract).

16. Alam, J.F.; Yamamoto, T.; Umino, T.; Nakahara, S.; Hiraoka, K. Modeling the efficacy of three types of artificial timber Reefs in Mitsu Bay, Japan. Water 2020, 12, 2013. [CrossRef]

17. Redfield, A.C. On the proportions of organic derivatives in sea water and their relation to the composition of plankton. In James Johnstone Memorial Volume; James, J., Daniel, R.J., Eds.; University Press of Liverpool: Liverpool, UK, 1934; pp. 176-192.

18. Sanyo Techno Marine. The Report on the Contract Project by the Ministry of the Environment Japan, "Healthy Plan for Sea Area" (Mitsu Bay), FY2013; Sanyo Techno Marine, Inc.: Tokyo, Japan, 2014.

19. Japan Meteorological Agency. Past Weather Data Search. Available online: http://www.data.jma.go.jp/ obd/stats/etrn/index.php?prec_no=67\&block_no=0686\&year=2018\&month=1\&day=\&view=p3 (accessed on 20 February 2020).

20. Yoshioka, K.; Kamiya, H.; Kano, Y.; Saki, Y.; Yamamuro, M.; Ishitobi, Y. The relationship between seasonal variations of total-nitrogen and total-phosphorus in rainfall and air mass advection paths in Matsue, Japan. Atmos. Environ. 2009, 43, 3496-3501. [CrossRef]

21. Hiroshima Prefecture Office. Publications. Available online: https://www.pref.hiroshima.lg.jp/soshiki/32/ suigi-top.html\#kannkoubutu (accessed on 20 September 2019).

22. Wang, H.; Appan, A.; Gulliver, J.S. Modeling of phosphorus dynamics in aquatic sediments: II-Examination of model performance. Water Res. 2003, 37, 3939-3953. [CrossRef]

23. Li, Y.-H.; Gregory, S. Diffusion of ions in sea water and in deep-sea sediments. Geochim. Cosmochim. Acta 1974, 38, 703-714.

24. Lee, I.C.; Hoshika, A. Prediction of oyster culture and water quality change in Hiroshima Bay development of water-sediment ecosystem model. Rep. Chugoku. Natl. Ind. Res. Inst. 2000, 54, 33-41.

25. Eppley, R.W.; Rogers, J.N.; McCarthy, J.J. Half-saturation constants for uptake of nitrate and ammonium by marine phytoplankton. Limnol. Oceanogr. 1969, 14, 912-920. [CrossRef]

26. Yanagi, T.; Onitsuka, G. Seasonal variation in lower trophic level ecosystem of Hakata Bay, Japan. J. Oceanogr. 2000, 56, 233-243. [CrossRef]

27. Hayashi, M.; Yanagi, T. Comparison of the lower trophic level ecosystem with Suo-Nada and the inner part of Osaka Bay. Ocean Jpn. 2002, 11, 591-611. [CrossRef]

28. Eppley, R.W. Temperature and phytoplankton growth in the sea. Fish Bull. 1972, 70, 1063-1085.

29. Kawamiya, M.; Kishi, M.J.; Yamanaka, Y.; Suginohara, N. An ecological-physical coupled model applied to Station Papa. J. Oceanogr. 1995, 51, 635-664. [CrossRef]

30. Wahyudin; Yamamoto, T. Modeling bottom-up and top-down controls on the low recruitment success of oyster larvae in Hiroshima Bay, Japan. Aquaculture 2020, 529, 735564. [CrossRef]

31. Gupta, H.V.; Sorooshian, S.; Yapo, P.O. Status of automatic calibration for hydrologic models: Comparison with multilevel expert calibration. J. Hydrol. Eng. 1999, 4, 135-143. [CrossRef]

32. Ostojski, M.S.; Gebala, J.; Orlińska-Woźniak, P.; Wilk, P. Implementation of robust statistics in the calibration, verification and validation step of model evaluation to better reflect processes concerning total phosphorus load occurring in the catchment. Ecol. Modell. 2016, 332, 83-93. [CrossRef] 
33. Falcão, M.; Santos, M.N.; Drago, T.; Serpa, D.; Monteiro, C. Effect of artificial reefs (southern Portugal) on sediment-water transport of nutrients: Importance of the hydrodynamic regime. Estuar. Coast Shelf. Sci. 2009, 83, 451-459. [CrossRef]

34. Rizzo, W.M. Nutrient exchanges between the water column and a subtidal benthic microalgal community. Estuaries 1990, 13, 219-226. [CrossRef]

35. Vicente, M.; Falcão, M.; Santos, M.N.; Caetano, M.; Serpa, D.; Vale, C.; Monteiro, C. Environmental assessment of two artificial reef systems off southern Portugal (Faro and Olhão): A question of location. Cont. Shelf Res. 2008, 28, 839-847. [CrossRef]

36. Kim, D.H.; Matsuda, O.; Yamamoto, T. Nitrification, denitrification and nitrate reduction rates in the sediment of Hiroshima Bay, Japan. J. Oceanogr. 1997, 53, 317-324.

37. Kemp, M.J.; Dodds, W.K. The influence of ammonium, nitrate, and dissolved oxygen concentrations on uptake, nitrification, and denitrification rates associated with prairie stream substrata. Limnol. Oceanogr. 2002, 47, 1380-1393. [CrossRef]

38. Cabrita, M.T.; Brotas, V. Seasonal variation in denitrification and dissolved nitrogen fluxes in intertidal sediments of the Tagus estuary, Portugal. Mar. Ecol. Prog. Ser. 2000, 202, 51-65. [CrossRef]

39. The Sectional Meeting on Aquatic Environment, Hyogo Prefectural Council for Environments. A Measure for Further Improvement of the Environment of Rich and Beautiful Seto Inland Sea. Available online: https://www.kankyo.pref.hyogo.lg.jp/files/4015/6455/8861/190806.pdf (accessed on 8 July 2020). (In Japanese).

(C) 2020 by the authors. Licensee MDPI, Basel, Switzerland. This article is an open access article distributed under the terms and conditions of the Creative Commons Attribution (CC BY) license (http://creativecommons.org/licenses/by/4.0/). 